\title{
Partisipasi Anggaran, Komitmen Organisasi dan Kinerja Manajerial dengan Gaya Kepemimpinan dan Budaya Organisasi sebagai Pemoderasi
}

\author{
Pemi Pangestu Andika \\ Universitas Pancasila , Jakarta, Indonesia
}

\section{INFO ARTIKEL \\ JEL Classification : M41, H83}

Keywords :

leadership style, budget participation, organizational commitment, organizational culture, managerial performance

\begin{abstract}
The success of an organization in achieving its goals depends largely on managerial performance. This study aims to analyze organizational participation and commitment to managerial performance through leadership styles and organizational culture as moderating variables. This study uses a quantitative approach by testing the hypothesis to see the correlation between budgetary participation and organizational commitment to managerial performance with leadership style and organizational culture as a moderating variable. The leadership style does not moderate budget participation and organizational commitment to managerial performance. Organizational culture moderates budget participation in managerial performance but organizational culture does not moderate the organizational commitment to managerial performance in the scope of the Directorate of Disease Prevention and Control of the Ministry of Health.
\end{abstract}

\begin{abstract}
ABSTRAK
Keberhasilan suatu organisasi dalam mencapai tujuan sebagian besar tergantung pada kinerja manajerial. Penelitian ini bertujuan untuk menganalisis partisipasi penyusunan dan komitmen organisasi terhadap kinerja manajerial melalui gaya kepemimpinan dan budaya organisasi sebagai variable moderasi. Gaya kepemimpinan tidak memoderasi partisipasi anggaran dan komitmen organisasi terhadap kinerja manajerial. Budaya organisasi memoderasi partisipasi anggaran terhadap kinerja manajerial tetapi budaya organisasi tidak memoderasi antara komitmen organisasi terhadap kinerja manajerial di ruang lingkup Direktorat Pencegahan Dan Pengendalian Penyakit Kementerian Kesehatan.
\end{abstract}

\section{Pendahuluan}

Anggaran merupakan komponen penting dalam perusahaan. Pentingnya fungsi anggaran sebagai perencana dan pengendali perusahaan menjadikan penganggaran sebagai hal yang penting bagi keberhasilan perusahaan. Anggaran adalah sebuah rencana tentang kegiatan di masa datang, yang mengidentifikasikan kegiatan untuk mencapai tujuan. Perencanaan dan pengendalian mempunyai hubungan yang sangat erat.
Perencanaan adalah melihat ke masa depan, menentukan kegiatan apa yang harus dilakukan untuk mencapai suatu tujuan. Pengendalian adalah melihat ke masa lalu, melihat apa yang senyatanya terjadi dan membandingkannya dengan hasil yang direncanakan sebelumnya. Sebuah organisasi membutuhkan anggaran untuk menerjemahkan keseluruhan strategi ke dalam tujuan jangka pendek dan jangka panjang. 
Salah satu faktor yang memiliki pengaruh positif, dalam hal ini meningkatkan kinerja karyawan adalah partisipasi anggaran. Partisipasi penyusunan anggaran yaitu suatu proses kerjasama dalam pembuatan keputusan yang melibatkan dua kelompok atau lebih yang berpengaruh pada pembuatan keputusan di masa yang akan datang. Disini partisipasi merupakan salah satu unsur yang sangat penting yang menekankan pada proses kerjasama dari berbagai pihak, baik bawahan maupun manajer level atas (French et al, 1960 dalam Omposunggu dan Bawono, 2006). Partisipasi penyusunan anggaran merupakan sebuah pendekatan manajerial yang umumnya dapat meningkatkan kinerja manajerial.

Partispasi anggaran berarti memberikan kesempatan kepada para bawahan untuk terlibat dalam penyusunan anggaran. Kinerja para karyawan akan meningkat apabila mereka terlibat secara aktif dalam proses penyusunan anggaran pada unit organisasi tempat mereka bekerja. Dengan adanya partisipasi dalam proses penyusunan anggaran, bawahan akan terlibat secara emosional yang pada gilirannya memunculkan rasa tanggung jawab yang lebih tinggi dalam pelaksanaan anggaran. Partisipasi anggaran juga memungkinkan bawahan untuk menentukan tujuan dan target mereka sendiri. Dengan demikian, mereka akan lebih terbuka untuk menerima anggaran dan bekerja dengan lebih untuk mencapai target tersebut.

Berdasarkan data laporan kinerja pemerintah yang di buat di direktorat Pencegahan dan pengendalian penyakit dimana kita bisa lihat bahwa ada bentuk grafik yang naik signifikan terhadap kinerjanya.

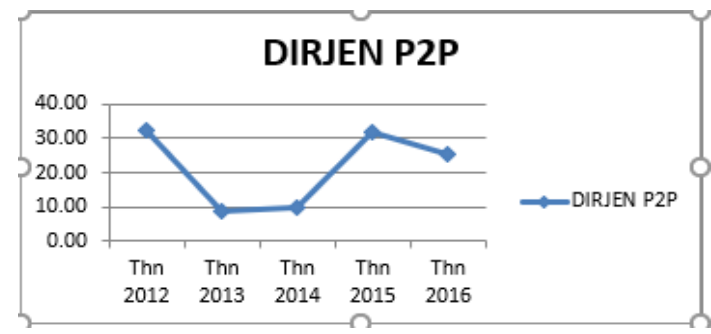

Gambar 1. Grafik Kinerja Dirjen P2P

Pada grafik tersebut direktorat Pencegahan dan Pengendalian Penyakit tahun 2013 dan 2014 mengalami penurunan, pada tahun 2015 dan 2016 direktorat Pencegahan dan
Pengendalian Penyakit mengalami peningkatan kinerja. Melihat fenomena tersebut penulis melihat adanya data yang bisa jadi bahan untuk diteliti.

Beberapa penelitian telah membuktikan secara empiris hubungan antara partisipasi anggaran dengan kinerja manajerial. Penelitian Nichlah, Ella (2010) membuktikan bahwa Partisipasi Anggaran berpengaruh positif signifikan terhadap Kinerja Manajerial. Hal tersebut didukung oleh penelitian Diana Eka Wulandari (2016) yang mengemukakan bahwa Penganggaran Partisipatif Berpengaruh positif Terhadap Kinerja Manajerial, dan beberapa penelitian lainnya oleh Sardjito dan Muthaher (2007), Mattola dan Pradina (2013) mengemukakan bahwa adanya pengaruh yang signifikan antara partisipasi anggaran dengan kinerja manajerial.

Akan tetapi, bukti empiris lain menunjukkan bahwa tidak selamanya partisipasi dalam penyusunan anggaran mempunyai pengaruh positif terhadap kinerja. Penelitian Milani membuktikan bahwa terdapat hubungan yang tidak signifikan antara partisipasi anggaran dengan pengukuran kinerja. Hal tersebut juga didukung oleh penelitian lainnya yaitu Yuliana (2014) dan Wicaksono (2016) yang mengemukakan bahwa Partisipasi anggaran tidak berpengaruh signifikan terhadap kinerja manajerial. Bukti empiris lainnya menunjukkan bahwa partisipasi dalam penyusunan anggaran mempunyai pengaruh negatif terhadap kinerja manajerial, dalam penelitian Medhayanti dan Suardana (2015) yang mengemukakan bahwa partisipasi penyusunan anggaran berpengaruh negatif terhadap kinerja manajerial

Pada variabel komitmen organisasi dan Locus of Control, dalam penelitian Sardjito dan Muthaher (2007) dan Mattola (2011) menunjukkan komitmen organisasi dan Locus of Control sebagai variabel moderating mempengaruhi secara signifikan hubugan partisipasi anggaran terhadap kinerja aparat pemerintah daerah (manajerial). Hal tersebut didukung oleh penelitian Sutrisni dan Rusman (2014) yang mengemukakan Komitmen organisasi memoderasi atau mempengaruhi terhadap hubungan partisipasi penyusunan anggaran dengan kinerja manajerial. 
Akan tetapi, bukti empiris lain menunjukkan bahwa tidak selamanya Komitmen organisasi mempunyai pengaruh terhadap kinerja manajerial. Penelitian Nurcahyani (2010) membuktikan bahwa komitmen organisasi tidak berpengaruh terhadap kinerja manajerial.

Pada Variabel Komitmen Organisasi terhadap Kinerja Manajerial dalam penelitian Randall (1990) dalam Nouri dan Parker (1998) menunjukkan komitmen Organisasi sebagai variabel moderating mempengaruhi secara signifikan hubungan partisipasi anggaran terhadap kinerja manajerial (Sardjito dan Muthaher, 2007:3).

Pada Variabel Partisipasi Anggaran terhadapa Kinerja manajeria yang dimoderasi oleh Gaya Kepemimpinan dan Budaya Organisasi mempunya pengaruh positif berdasarkan penelitian Soleman Rusman (2012)

\section{Telaah Teori dan Pengembangan}

\section{Hipotesis}

\section{Kerangka Pemikiran}

Kerangka pemikiran merupakan model konseptual tentang bagaimana teori berhubungan dengan berbagai faktor yang telah diidentifikasi sebagai masalah yang penting. Kerangka pemikiran yang baik akan menjelaskan secara teoritis pertautan antara variabel yang diteliti sehingga secara teoritis dapat menjelaskan hubungan antara variabel independen dan dependen. Dari penelitianpenelitian terdahulu yang telah dibahas sebelumnya yang menyatakan bahwa adanya pengaruh partisipasi anggaran terhadap kinerja manajerial dengan Gaya Kepemimpinan dan Budaya Organisasi sebagai pemoderasi dan pengaruh Komitmen Organisasi terhadap kinerja manajerial dengan Gaya Kepemimpinan dan Budaya Organisasi sebagai pemoderasi, maka berikut ini merupakan model penelitian dari penelitian ini:

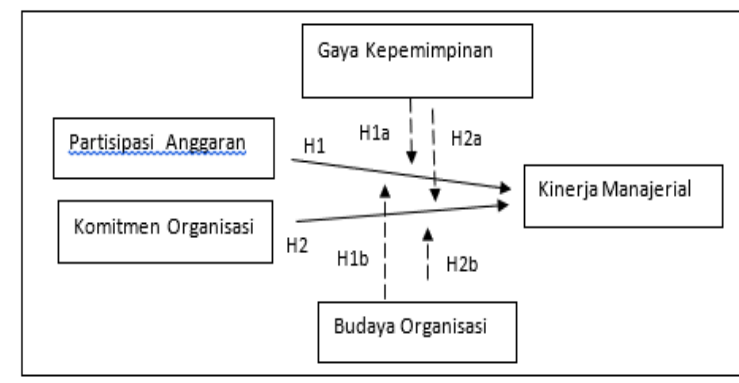

Gambar 2. Model Penelitian

\section{Partisipasi Anggaran}

Dalam organisasi sektor publik, partisipasi anggaran dan pengukuran kinerja tidak sebatas pada masalah pemakaian anggaran, namun pengukuran kinerja mencakup berbagai aspek yang dapat memberikan informasi yang efisien dan efektif dalam mencapai hasil yang diinginkan kinerja. Aspek-aspek yang dapat memberikan informasi yang efektif dan efisien seperti masukan, kualitas, keluaran, hasil, efisiensi. Dalam hal ini penyusunan anggaran digunakan dalam pendekatan kinerja, maka setiap alokasi biaya yang direncanakan harus dikaitkan dengan tingkat pelayanan atau hasil yang diharapkan tercapai. Kinerja pemerintah daerah dapat diukur melalui evaluasi akuntanbilitas kinerja instansi pemerintah (Permenpan No 35 tahun 2011).

Anggaran yang telah disusun memiliki peranan sebagai perencanaan dan sebagai kriteria kinerja, yaitu anggaran dipakai sebagai suatu sistem pengendalian untuk mengukur kinerja aparat pemerintah daerah (Lewin,1970). Menurut Agyris (1952) untuk mencegah dampak fungsional atau disfungsional, sikap dan perilaku anggota organisasi dalam penyusunan anggaran perlu melibatkan bawahan (aparat pemerintah daerah). Sehingga partisipasi anggaran dapat dinilai sebagai pendekatan aparat pemerintah daerah yang dapat meningkatkan kinerja setiap anggota organisasi sebagai individual karena dengan adanya partisipasi dalam penyusunan anggaran diharapkan setiap aparat pemerintah daerah mampu meningkatkan kinerjanya sesuai dengan target yang telah ditetapkan sebelumnya. Menurut Muthaher (2007) dalam penelitiannya menemukan hubungan positif dan signifikan antara partisipasi penganggaran dengan kinerja aparat pemerintah daerah. Namun demikian 
hasil penelitian Arifah (2009) menunjukkan bahwa terjadi hubungan yang tidak signifikan antara partisipasi dalam penyusunan anggaran dengan kinerja aparat pemerintah daerah. Sesuai dengan hasil penelitian yang telah dilakukan maka penelitian ini dimaksudkan untuk menguji kembali pengaruh partisipasi penyusunan anggaran terhadap kinerja aparat pemerintah daerah. Berdasarkan uraian di atas diusulkan hipotesis:

\section{H1: Partisipasi anggaran berpengaruh terhadap kinerja manajerial.}

\section{Pengaruh Partisipasi Anggaran Terhadap Kinerja Manajerial Dengan Gaya Kepemimpinan Organisasi Sebagai Variabel Moderasi}

Gaya kepemimpinan (leadership styles) merupakan cara pemimpin untuk mempengaruhi orang lain/bawahannya sedemikian rupa sehingga orang tersebut mau melakukan kehendak pemimpin untuk mencapai tujuan organisasi meskipun secara pribadi hal tersebut tidak disenangi (Siagian, 2003). Hasil studi Likert dan Araki (1989) menemukan bahwa; manajer yang berorientasi pada produk menetapkan standar kerja yang kaku, merinci pekerjaan sampai pada hal yang terkecil, menentukan metode kerja yang harus diikuti serta mengawasi karyawan dengan ketat. Sedangkan manajer yang berorientasi pada karyawan mendorong partisipasi karyawan dalam menentukan sasaran dan keputusan lain yang menyangkut dengan pekerjaan serta membantu memastikan prestasi kerja yang tinggi dengan membangkitkan kepercayaan dan penghargaan. Hasil penelitian mereka juga menemukan bahwa kelompok kerja yang produktif cenderung mempunyai pemimpin yang berorientasi pada karyawan ketimbang berorientasi pada produksi.

Selain itu mereka juga menemukan bahwa pemimpin yang paling efektif mempunyai hubungan saling mendukung dengan karyawan mereka, cenderung tergantung pada pembuatan keputusan kelompok daripada individu. Xenikou and Simosi (2006) dalam penelitiannya menemukan bahwa gaya kepemimpinan transformasional dan orientasi humanistik memiliki dampak positif secara tidak langsung terhadap kinerja melalui orientasi prestasi.
Patiar and Mia (2009) juga menemukan bahwa gaya kepemimpinan transformasional secara positif berpengaruh terhadap kinerja non keuangan dan pada pada akhirnya berpengaruh terhadap kinerja keuangan departemen. Dari uraian tersebut maka dapat disimpulkan bahwa gaya kepemimpinan adalah cara yang digunakan oleh seseorang untuk mempengaruhi, mengarahkan, mendorong dan mengendalikan bawahannya dalam rangka pencapaian tujuan oraganisasi. Dengan demikian maka gaya kepemimpinan mendorong inovasi bawahan untuk membantu pencapaian kinerja secara berkesinambungan.

H1a: Partisipasi Anggaran berpengaruh positif terhadap kinerja manajerial dengan Gaya Kepemimpinan sebagai variabel pemoderasi.

\section{Pengaruh Partisipasi Anggaran Terhadap Kinerja Manajerial Dengan Budaya Organisasi Organisasi Sebagai Variabel Moderasi}

Menurut Hofstede (1984), kultur merupakan keseluruhan pola pemikiran, perasaan dan tindakan dari suatu kelompok sosial, yang membedakan dengan kelompok sosial yang lain. Ini berarti bahwa kultur memainkan peran penting dalam membentuk karakter bagi sebuah organisasi dan menjadi ciri pembeda antara satu organisasi dengan organisai yang lain hal ini dikarenakan bahwa budaya organisasi menjadi suatu proses perubahan yang akan membawa organisasi pada pencapaian tujuan strategis.

Hofstede et al. (1990) membagi kultur organisasional ke dalam enam dimensi praktis: (1) Process-Oriented vs. ResultsOriented, (2) Employee-Oriented vs. JobOriented, (3) Parochial vs Professional, (4) Open system vs. Closed System, (5) Loose Control vs. Tight Control, (6) Normative vs. Pragmatic. Dari keenam dimensi pratik kultur organisasional tersebut, menurut Hofstede et al. (1990) yang mempunyai kaitan erat dengan praktik-praktik pembuatan keputusan partisipatif adalah dimensi praktik yang kedua, yaitu orientasi pada orang (employee oriented) dan orientasi pada pekerjaan (job oriented).

Schein (1985) mendefinisikan budaya sebagai asumsi dasar dan keyakinan yang di anut oleh anggota organisasi. Sedangkan hasil penelitian dari Subramaniam and Ashkanasy 
(2001) menyimpulkan bahwa budaya organisasi mempunyai pengaruh yang signifikan dalam memoderasi hubungan partisipasi anggaran dan kinerja manajer. Damayanti (2007) menegaskan bahwa budaya organisasi memoderasi hubungan antara partisipasi anggaran dan kinerja manajerial, demikian juga dengan Yiing and Ahmad (2009) menyimpulkan bahwa perilaku kepemimpinan dan komitmen organisasi di moderasi oleh budaya organisasi.

Hal ini diperkuat oleh hasil penelitan oleh Alam and Mia (2006) yang menemukan bahwa budaya mempengaruhi sikap para manajer untuk berpartisipasi dalam penyusunan anggaran, dengan semakin tinggi tingkat partisipasi mereka dalam penyusunan anggaran maka semakin tinggi kinerja mereka. Dari hasil penelitian terhadap para pegawai pemerintah daerah (LGAs) di Malaysia, Taylor et al. (2008) juga menemukan hal yang sama bahwa budaya mempunyai pengaruh terhadap efek akuntabilitas, partisipasi anggaran dan kinerja manajerial. Dari berbagai uraian di atas dapat disimpulkan bahwa budaya organisasi mempunyai pengaruh positif terhadap kinerja manajerial.

H1b: Partisipasi Anggaran berpengaruh positif terhadap kinerja manajerial dengan budaya organisasi sebagai variabel pemoderasi.

\section{Komitmen Organisasi}

Komitmen organisasi adalah dorongan dari dalam individu untuk berbuat sesuatu agar dapat menunjang keberhasilan organisasi sesuai dengan tujuan dan lebih mengutamakan kepentingan organisasi dibandingkan dengan kepentingan sendiri (Weiner dalam Coryanata, 2002). Kecukupan anggaran tidak hanya secara langsung meningkatkan prestasi kerja, tetapi juga secara tidak langsung (moderasi) melalui komitmen organisasi. Komitmen yang tinggi menjadikan individu lebih mementingkan organisasi daripada kepentingan pribadi dan berusaha menjadikan organisasi menjadi lebih baik. Komitmen organisasi yang rendah akan membuat individu untuk berbuat untuk kepentingan pribadinya. Selain itu, komitmen organisasi dapat merupakan alat bantu psikologis dalam menjalankan organisasinya untuk pencapaian kinerja yang diharapkan (Nouri dan Parker,
1996; McClurg, 1999; Chong dan Chong, 2002; Wentzel, 2002). Komitmen organisasi yang tinggi akan meningkatkan kinerja yang tinggi pula (Randall ,1990 dalam Nouri dan Parker, 1998). Berdasarkan hasil penelitian yang berkaitan dengan komitmen organisasi, ditentukan bahwa komitmen organisasi mempunyai pengaruh positif terhadap partisipasi penyusunan anggaran dalam meningkatkan kinerja aparat pemerintah.

H2: Komitmen organisasi berpengaruh terhadap kinerja manajerial.

\section{Pengaruh Komitmen Organisasi terhadap kinerja manajerial dengan Gaya Kepemimpinan sebagai variabel moderasi}

Hasil penelitian Yiing and Ahmad (2009) menemukan bahwa perilaku kepemimpinan dan budaya suportif memoderasi hubungan antara komitmen dan kepuasan kerja. Darma, (2002) dalam penelitiannya menemukan bahwa partisipasi yang tinggi dalam penyusunan angggaran mempunyai pegaruh positif terhadap kinerja manajerial pada kultur organisasional yang berorientasi pada orang dan berpengaruh negatif pada kultur organisasional yang berorinetasi pekerjaan. Hasil ini menjelaskan bahwa partisipasi bawahan dalam penyusunan anggaran kemungkinan lebih efektif jika keputusankeputusan penting dalam organisasi lebih sering dibuat secara berkelompok.

Dari berbagai uraian di atas dapat disimpulkan bahwa gaya kepemimpinan mempunyai pengaruh positif terhadap kinerja manajerial.

H2a: Komitmen Organisasi berpengaruh positif terhadap kinerja manajerial dengan gaya kepemimpinan sebagai variabel pemoderasi.

\section{Pengaruh Komitmen Organisasi terhadap kinerja manajerial dengan Budaya Organisasi sebagai variabel moderasi}

Hasil penelitian Arifin (2012) menemukan bahwa Tingkat komitmen organisasi yang tinggi akan menjadikan individu lebih mementingkan organisasi daripada kepentingan pribadinya, sehingga tiap-tiap individu akan selalu meningkatkan kinerjanya karena mereka akan selalu berusaha agar organisasi tersebut dapat mencapai tujuan yang diharapkan, tetapi dengan moderasi variabel budaya organisasi tidak dapat 
memberi pengaruh partisipasi anggaran terhadap kinerja pegawai. Hasil penelitian Yiing and Ahmad (2009) menemukan bahwa perilaku kepemimpinan dan budaya suportif memoderasi hubungan antara komitmen dan kepuasan kerja.

Dari berbagai uraian di atas dapat disimpulkan bahwa budaya organisasi bisa mempunyai pengaruh positif atau tidak terhadap kinerja manajerial.

$\mathrm{H} 2 \mathrm{~b}$ : Komitmen Organisasi berpengaruh positif terhadap kinerja manajerial dengan budaya organisasi sebagai variabel pemoderasi.

\section{Metode Penelitian}

Konversi diagram alur ke dalam persamaan Dibangun sebagai berikut:

$$
\begin{aligned}
\mathrm{Y} 1= & \mathrm{a}+\mathrm{b} 1 . \mathrm{PA}+\mathrm{b} 2 . \mathrm{KO}+\mathrm{b} 3[(\mathrm{PA} * \mathrm{GK})]+ \\
& \mathrm{b} 4[(\mathrm{PA} * \mathrm{BO})]+\mathrm{b} 5[(\mathrm{KO} * \mathrm{GK})]+ \\
& \mathrm{b} 6[(\mathrm{KO} * \mathrm{BO})]+\mathrm{e}
\end{aligned}
$$

Keterangan :

$\mathrm{Y} 1=$ Kinerja Manajerial

$\mathrm{a}=$ Nilai $\mathrm{Y}$ pada perpotongan antara garis linear dengan sumbu vertikal

$\mathrm{PA}=$ Partisipasi Anggaran

$\mathrm{KO}=$ Komitmen Organisasi

GK = Gaya Kepemimpinan

$\mathrm{BO}=$ Budaya Organisasi

b1 $=$ Koefisien partisipasi anggaran

b2 = Koefisien komitmen organisasi

b3 = Koefisien Gaya Kepemimpinan

$\mathrm{b} 4=$ Koefisien Budaya Organisasi

\section{Hasil Penelitian dan Pembahasan}

\section{Pengaruh Partisipasi Anggaran Terhadap Kinerja Manajerial}

Hasil pengujian pengaruh partisipasi anggaran terhadap kinerja manajerial pada tabel 5 dapat dilihat bahwa koefisien jalur sebesar 0.53, $p$ value sebesar $0,01(p<0,05)$ dan standar error koefisien jalur sebesar 0,096. Berdasarkan hasil tersebut Partisipasi Anggaran berpengaruh positif dan signifikan terhadap Kinerja Manajerial. Partisipasi penyusunan anggaran merupakan keterlibatan seluruh Kepala Bidang dan Bagian (lini menengah ke bawah) dalam suatu instansi untuk melakukan kegiatan dalam pencapaian sasaran yang telah ditetapkan dalam anggaran.
Dengan adanya keterlibatan tersebut akan mendorong para Kepala Bidang dan Bagian untuk bertanggung jawab terhadap masingmasing tugas yang diembannya sehingga para Kepala bidang dan kepala bagian akan meningkatkan kinerjanya agar mereka dapat mencapai sasaran atau target yang telah ditetapkan dalam anggaran. Hal ini mengindikasikan adanya hubungan yang positif antara partisipasi penyusunan anggaran dengan kinerja manajerial. Hasil penelitian ini sejalan dengan hasil penelitian yang telah dilakukan oleh Indriantoro (1993) dalam Sardjito dan Muthaher (2007). Ada penelitian yang lain yang yang menunjukkan bahwa hubungan partisipasi anggaran dengan kinerja terdapat pengaruh negatif terdapat dalam penelitian Medhayanti dan Suardana (2015). Pada penelitian terdahulu dan sekarang yang membedakan adalah wilayah anggaran dimana penelitian terdahulu menggunakan APBD yang sekarang APBN. Teori ini mendukung sesuai dengan teori utama yaitu teori kontinjensi dimana diperlukan penyelesaikan berbagai perbedaan pendapat tersebut.

\section{Partisipasi Anggaran berpengaruh terhadap kinerja manajerial dengan Gaya Kepemimpinan sebagai variabel pemoderasi}

Hasil pengujian pengaruh partisipasi anggaran terhadap kinerja manajerial dengan Gaya Kepemimpinan sebagai variabel pemoderasi pada tabel 5 dapat dilihat bahwa koefisien jalur sebesar -0.01 , $p$ value sebesar $0,46(p>0,05)$ dan standar error koefisien jalur sebesar 0,096. karena itu pengujian terhadap persamaan model kedua menghasilkan kesimpulan yang tidak konsisten dengan hipotesis 1 (H1a ditolak) yaitu Partisipasi Anggaran berpengaruh positif terhadap kinerja manajerial dengan Gaya Kepemimpinan sebagai variabel pemoderasi. Hasil penelitian ini sejalan dengan hasil penelitian yang telah dilakukan oleh Amertadewi dan Dwirandra (2013) yaitu pengaruh partisipasi anggaran terhadap kinerja manajerial dengan gaya kepemimpinan sebagai variabel moderasi dengan hasil berpengaruh negatif. Ada hasil penelitian lain yang telah dilakukan oleh Patiar and Mia (2009) yaitu menemukan bahwa gaya kepemimpinan transformasional 
secara positif berpengaruh terhadap kinerja non keuangan dan pada pada akhirnya berpengaruh terhadap kinerja keuangan departemen. Pada penelitian terdahulu dan sekarang yang membedakan adalah tempat penelitian dimana penelitian terdahulu menggunakan Bank Daerah yang sekarang Kementerian Kesehatan. Teori ini mendukung sesuai dengan teori utama yaitu teori kontinjensi dimana diperlukan penyelesaikan berbagai perbedaan pendapat tersebut.

\section{Pengaruh Partisipasi Anggaran Terhadap Kinerja Manajerial Dengan Budaya Organisasi Sebagai Variabel Moderasi \\ Hasil pengujian pengaruh partisipasi} anggaran terhadap kinerja manajerial dengan budaya organisasi sebagai variabel pemoderasi pada tabel 5 dapat dilihat bahwa koefisien jalur sebesar -0.27 , $\mathrm{p}$ value sebesar $0,01(\mathrm{p}<0,05)$ dan standar error koefisien jalur sebesar 0,096. karena itu pengujian terhadap persamaan model ketiga menghasilkan kesimpulan yang konsisten dengan hipotesis 1 (H1b diterima) yaitu Partisipasi Anggaran berpengaruh terhadap kinerja manajerial dengan Budaya Organisasi sebagai variabel pemoderasi. Hal ini diperkuat oleh hasil penelitan oleh Alam and Mia (2006) yang menemukan bahwa budaya mempengaruhi sikap para manajer untuk berpartisipasi dalam penyusunan anggaran, dengan semakin tinggi tingkat partisipasi mereka dalam penyusunan anggaran maka semakin tinggi kinerja mereka. Dari hasil penelitian terhadap para pegawai pemerintah daerah (LGAs) di Malaysia. Ada hasil penelitian lain yang telah dilakukan oleh Restu Agusti (2012) yaitu Hasil pengujian hipotesis ketiga menunjukkan bahwa budaya organisasi berpengaruh negatif terhadap hubungan antara partisipasi penyusunan anggaran terhadap kinerja aparat pemda. Pada penelitian terdahulu dan sekarang yang membedakan adalah tempat penelitian dimana penelitian terdahulu menggunakan Pemerintah daerah malaysia yang sekarang Kementerian Kesehatan di indonesia. Teori ini mendukung sesuai dengan teori utama yaitu teori kontinjensi dimana diperlukan penyelesaikan berbagai perbedaan pendapat tersebut.

\section{Pengaruh Komitmen Terhadap Kinerja Manajerial}

Hasil pengujian pengaruh partisipasi anggaran terhadap kinerja manajerial dengan budaya organisasi sebagai variabel pemoderasi pada tabel 5 dapat dilihat bahwa koefisien jalur sebesar 0.22 , p value sebesar $0,02(\mathrm{p}<0,05)$ dan standar error koefisien jalur sebesar 0,096. karena itu pengujian terhadap persamaan model keempat menghasilkan kesimpulan yang konsisten signifikan dengan hipotesis dua ( $\mathrm{H} 2$ tidak ditolak) yaitu Komitmen Organisasi berpengaruh positif dan signifikan terhadap Kinerja Manajerial. komitmen organisasi merupakan keterlibatan seluruh Kepala Bidang dan Bagian (lini menengah ke bawah) dalam suatu instansi untuk melakukan kegiatan dalam pencapaian sasaran yang telah ditetapkan dalam anggaran. Dengan adanya keterlibatan tersebut akan mendorong para Kepala Bidang dan Bagian untuk bertanggung jawab terhadap masing-masing tugas yang diembannya sehingga para Kepala bidang dan kepala bagian akan meningkatkan kinerjanya agar mereka dapat mencapai sasaran atau target yang telah ditetapkan dalam anggaran. Hal ini mengindikasikan adanya hubungan yang positif antara komitmen organisasi dengan kinerja manajerial (H2). Hasil penelitian ini sejalan dengan hasil penelitian yang telah dilakukan oleh Bambang Sardjito dan Osmad Muthaher (2007) yaitu semakin tingkat komitmen organisasi akan menyebabkan peningkatan kinerja aparat pemerintah daerah dalam partisipasi penyusunan anggaran. Ada penelitian yang lain yang yang menunjukkan bahwa hubungan komitmen Organisasi tidak berpengaruh dengan kinerja manajerial terdapat dalam penelitian Kunwaviyah Nurcahyani (2010). Pada penelitian terdahulu dan sekarang yang membedakan adalah wilayah anggaran dimana penelitian terdahulu menggunakan APBD yang sekarang APBN. Teori ini mendukung sesuai dengan teori utama yaitu teori kontinjensi dimana diperlukan penyelesaikan berbagai perbedaan pendapat tersebut.

\section{Pengaruh Komitmen Organisasi terhadap kinerja manajerial dengan Gaya Kepemimpinan sebagai variabel moderasi}

Hasil pengujian pengaruh Pengaruh Komitmen Organisasi terhadap kinerja manajerial dengan Budaya Organisasi sebagai 
variabel moderasi pada tabel 5 dapat dilihat bahwa koefisien jalur sebesar -0.07 , $\mathrm{p}$ value sebesar 0,26 $(\mathrm{p}>0,05)$ dan standar error koefisien jalur sebesar 0,096. karena itu pengujian terhadap persamaan model kelima menghasilkan kesimpulan yang tidak konsisten dengan hipotesis 2 (H2a ditolak) yaitu Komitmen Organisasi berpengaruh terhadap kinerja manajerial dengan Gaya Kepemimpinan sebagai variabel pemoderasi. komitmen organisasi terhadap kinerja manajerial. Penelitian ini sesuai dengan hasil penelitian Triseptya, Pagalung, Indrijawati (2015), yang berpendapat bahwa gaya kepemimpinan yang baik tidak serta merta mempengaruhi komitmen karyawan untuk tetap tinggal di organisasi. Pada penelitian terdahulu dan sekarang yang membedakan adalah wilayah kerja dimana penelitian terdahulu menggunakan wilayah makassar yang sekarang jakarta. Teori ini mendukung sesuai dengan teori utama yaitu teori kontinjensi dimana diperlukan penyelesaikan berbagai perbedaan pendapat tersebut.

\section{Pengaruh Partisipasi Anggaran Terhadap Kinerja Manajerial Dengan Budaya Organisasi Sebagai Variabel Moderasi}

Hasil pengujian pengaruh partisipasi anggaran terhadap kinerja manajerial dengan budaya organisasi sebagai variabel pemoderasi pada tabel 5 dapat dilihat bahwa koefisien jalur sebesar $-0.10, \mathrm{p}$ value sebesar $0,19(\mathrm{p}>0,05)$ dan standar error koefisien jalur sebesar 0,096. karena itu pengujian terhadap persamaan model keenam menghasilkan kesimpulan yang tidak konsisten dengan hipotesis 2 ( $\mathrm{H} 2 \mathrm{~b}$ tidak diterima) yaitu Komitmen Organisasi berpengaruh terhadap kinerja manajerial dengan Budaya Organisasi sebagai variabel pemoderasi. Belum ada penelitian yang membuat variabel $\mathrm{x}$ nya komitmen organisasi dan budaya organisasi sebagai variabel pemoderasi.

\section{Kesimpulan, Keterbatasan Dan Implikasi Hasil Penelitian}

Partisipasi Anggaran berpengaruh positif dan signifikan terhadap Kinerja Manajerial. Partisipasi penyusunan anggaran merupakan keterlibatan seluruh Kepala Bidang dan Bagian (lini menengah ke bawah) dalam suatu instansi untuk melakukan kegiatan dalam pencapaian sasaran yang telah ditetapkan dalam anggaran.

Partisipasi Anggaran berpengaruh negatif terhadap kinerja manajerial dengan Gaya Kepemimpinan sebagai variabel pemoderasi dan menghasilkan kesimpulan yang tidak konsisten. Sesuai dengan penelitian yang dilakukan dimana pengaruh partisipasi anggaran terhadap kinerja manajerial dengan gaya kepemimpinan sebagai variabel moderasi dengan hasil berpengaruh negatif.

Partisipasi Anggaran Terhadap Kinerja Manajerial Dengan Budaya Organisasi Sebagai Variabel Moderasi. Bahwa budaya mempengaruhi sikap para manajer untuk berpartisipasi dalam penyusunan anggaran, dengan semakin tinggi tingkat partisipasi mereka dalam penyusunan anggaran maka semakin tinggi kinerja mereka.

Komitmen Organisasi berpengaruh positif dan signifikan terhadap Kinerja Manajerial. komitmen organisasi merupakan keterlibatan seluruh Kepala Bidang dan Bagian (lini menengah ke bawah) dalam suatu instansi untuk melakukan kegiatan dalam pencapaian sasaran yang telah ditetapkan dalam anggaran. Dengan adanya keterlibatan tersebut akan mendorong para Kepala Bidang dan Bagian untuk bertanggung jawab terhadap masingmasing tugas yang diembannya sehingga para Kepala bidang dan kepala bagian akan meningkatkan kinerjanya.

Komitmen Organisasi berpengaruh terhadap kinerja manajerial dengan Gaya Kepemimpinan sebagai variabel pemoderasi dan menghasilkan kesimpulan yang tidak konsisten.

Komitmen Organisasi berpengaruh terhadap kinerja manajerial dengan Budaya Organisasi sebagai variabel pemoderasi dan menghasilkan kesimpulan yang tidak konsisten.

Penelitian ini merupakan metode survey menggunakan kuesioner dimana responden hanya terbatas pada eselon 2, 3, 4 dan Staf Perencanaan dan Laporan di Direktorat Pencegahan dan Pengendalian Penyakit sehingga ada kemungkinan berbeda dengan direktorat lain di lingkungan kementerian kesehatan maupun lintas sektor kementerian pemerintah. 
3. Data yang dianalisis dalam penelitian ini menggunakan instrumen yang berdasarkan persepsi jawaban responden.

\section{Daftar Pustaka}

Sardjito, B., \& Muthaher, O. (2007). Pengaruh Partisipasi Penyusunan Anggaran Terhadap Kinerja Aparat Pemda: Budaya dan Komitmen Organisasi sebagai Variabel Moderating. Simposium Nasional Akuntansi X, 26-28.

Brownell, P. (1982). A Field Study Examination of Budgetary Participation and Locus of Control. The Accounting Review, Vol. VII, No.4. October: 766-777.

Damayanti, T. (2007). Pengaruh Komitmen Anggaran Dan Kultur Organisasional Terhadap Hubungan Partisipasi Penganggaran Dan Kinerja Manajerial Pada Kondisi Stretch Targets. JAAI, Volume 11, No.1 (2007): 81-101.

Djaddang, S., \& Sulistiawarni, E. (2018). Riset Empirik Manajemen Akrual (Artificial Smoothing) dan Volatilitas Laba Pada Perusahaan Hedged di Indonesia. Semarang: Tiga Media Semarang.

Friyanty, I. (2016). Faktor- Faktor Yang Mempengaruhi Kinerja Manajerial Aparat Pemerintahan ( Studi Kasus Pemerintah Daerah Indramayu). Jurnal Tekun, Volume VII, No.01, (2016): 62-79.

Ghozali, I.. (2013). Aplikasi Analisis Multivariate dengan Program IBM SPSS 21 Update PLS Regresi. Semarang: Badan Penerbit Universitas Diponegoro.

Hidayah, N., \& Fauziah, F. E. (2010). Pengaruh Partisipasi Anggaran Terhadap Kinerja Manajerial Dengan Komitmen Organisasi Sebagai Variabel Moderating. Jurnal Dinamika Ekonomi dan Bisnis, (2010): 57-79.

Indarto, S. L., \& Ayu, S. D. (2011). Pengaruh Partisipasi dalam Penyusunan Anggaran terhadap Kinerja Manajerial Perusahaan melalui Kecukupan Anggaran, Komitmen Organisasi, Komitmen Tujuan Anggaran, dan Job Relevant Information (JRI). Seri Kajian Ilmiah, 14(1), 1-22.
Ompusunggu, K. B., \& Bawono, I. R. (2006). Pengaruh Partisipasi Anggaran dan Job Relevant Information (JRI) terhadap Informasi Asimetris (Studi pada Badan Layanan Umum Universitas Negeri di Kota Purwokerto Jawa Tengah). Simposium Nasional Akuntansi IX Padang, 23-26.

Latuheru, B. P. (2005. Pengaruh Partisipasi Anggaran Terhadap Senjangan Anggaran Dengan Komitmen Organisasi Sebagai Variabel Moderating. Jurnal Akuntansi \& Keuangan, vol. 7 no. 2, Nopember 2005, 117- 130.

Mahoney, T. A. T. H. Jerdee dan SJ, Carroll. 1963. Development of Managerial Performance. A Research Approach. Cincinnati. Ohio: South Western Publishing Co.

Mardiasmo. (2002). Akuntansi Sektor Publik, Edisi II. Penerbit Andi. Yogyakarta.

Milani, K. (1975). The Relationship of Participation in Budget-Setting to Industrial Supervisor Performance and Attitudes: A Field Study. The Accounting Review. pp. 274-284.

Moheri, Y., \& Arifah, D. A. (2015). Pengaruh Partisipasi Anggaran Terhadap Kinerja Manajerial. Jurnal Ekonomi \& Bisnis, 16(1), 86-93.

Pradina, I. I. Pengaruh Partisipasi Anggaran Terhadap Kinerja Manajerial Dengan Pelimpahan Wewenang Sebagai Variabel Moderating.

Puspaningsih, A. (2002). Pengaruh Partisipasi Dalam Penyusunan Anggaran Terhadap Kepuasan Kerja dan Kinerja Manajer. Jurnal Fakultas Hukum UII, 6(2).

Sinuraya, C. (2011). Pengaruh Partisipasi Penyusunan Anggaran terhadap Kinerja Manajer: Peran Kecukupan Anggaran dan Job-Relevant Information sebagai Variabel Intervening. Jurnal Akuntansi Maranatha, $1(1), 17-39$.

Soleman, R. (2012). Pengaruh Penganggaran Partisipatif terhadap Kinerja Manajerial dengan Budaya Organisasi dan Gaya Kepemimpinan sebagai Variabel 
Moderating. Jurnal Fakultas Hukum UII, 16(1).

Sulistyani, M. (2012). Pengaruh Partisipasi Penyusunan Anggaran Terhadap Kinerja Manajerial: Pelimpahan Wewenang Sebagai Variabel Moderating:(Studi Kasus pada Rumah Sakit Umum Daerah Banyudono di Kabupaten Boyolali) (Doctoral dissertation, Universitas Muhammadiyah Surakarta).

Wicaksono, G. (2016). Pengaruh partisipasi penyusunan anggaran terhadap kinerja manajerial pada sekolah menengah negeri di tegal. Esensi: Jurnal Bisnis dan Manajemen, 6(2), 199-212.

Wulandari, N. E., Mutmainah, S., \& Mutmainah, S. (2011). Pengaruh Partisipasi Penyusunan Anggaran Terhadap Kinerja Aparat Pemerintah
Daerah: Kepuasan Kerja dan Komitmen Organisasi Sebagai Variabel Moderating (Doctoral dissertation, Universitas Diponegoro).

Yuliana, R. (2014). Pengaruh Partisipasi Anggaran Terhadap Kinerja Manajerial Melalui Trust Dan Self-Efficacy Sebagai Variabel Intervening (Doctoral dissertation, Fakultas Ekonomi).

Ghozali, I., \& Yusfaningrum, K. (2005). Analisis Pengaruh Partisipasi Anggaran terhadap Kinerja Manajerial melalui Komitmen Tujuan Anggaran dan Job Relevant Information (JRI) sebagai Variabel Intervening. Penelitian terhadap Perusahaan Manufaktur di Indonesia). Simposium Nasional Akuntansi, (2005), 656-666. 